\title{
Rearing of Burbot, Lota lota (Pisces, Teleostei), Larvae with Zooplankton and Formulated Microdiets
}

\author{
Franz Lahnsteiner ${ }^{1}$, Manfred Kletzl ${ }^{2}$ \& Thomas Weismann ${ }^{3}$ \\ ${ }^{1}$ Department for Organismic Biology, University of Salzburg, Hellbrunnerstrasse 34, 5020 Salzburg, Austria \\ ${ }^{2}$ Fishfarm Kreuzstein, Oberburgau 28, 4866 Unterach, Austria \\ ${ }^{3}$ Bundesamt für Wasserwirtschaft, Institut für Gewässerökologie, Fischereibiologie und Seenkunde, Scharfling \\ 18, 5310 Mondsee, Austria
}

Correspondence: Franz Lahnsteiner, Department for Organismic Biology, University of Salzburg, Hellbrunnerstrasse 34, 5020 Salzburg, Austria. Tel: 43-662-8044-5630. E-mail: Franz.Lahnsteiner@sbg.ac.at

Received: June 6, 2012 Accepted: June 25, 2012 Online Published: August 8, 2012

doi:10.5539/jas.v4n9p269 URL: http://dx.doi.org/10.5539/jas.v4n9p269

\begin{abstract}
Different feeding methods were tested for burbot, Lota lota, larvae. In small scale experiments with 300 larvae per treatment grinded artemia flakes, enriched artemia flakes, artemia flakes supplemented with dried algae (Chlorella sp., Spirulina sp.) and formulated microdiets consisting of different combinations of fishmeal, fish oil, soybean lecithin, casein, dextran, and artemia flakes were fed over a period of 30 days. These foods were compared to live zooplankton food collected from the nature. After 30 days, only feeding with live zooplankton resulted in high survival rates $>80 \%$. No survival was observed with artificial microdiets. The $15 \mathrm{~d}$ survival of larvae was significantly lowest with agar agar bound microparticles and with formulated diets containing $\geq 7 \%$ soya lecithin and $\geq 3 \%$ fish oil. The live zooplankton feeding method was also tested in a large scale experiment with 25,000 larvae per tank for a period of $100 \mathrm{~d}$. After $100 \mathrm{~d}$ the larvae survival rate was $>65 \%$, and the body length had increased for circa 6-fold.
\end{abstract}

Keywords: larvae, Lota lota, nutrition, zooplankton, formulated diets

\section{Introduction}

In nature newly hatched fish larvae feed on zooplankton (Poulet \& Williams, 1991; Hsieh \& Chiu, 2002). For intensive culture conditions zooplankton is generally not available and live food (mainly Brachionus caIyciflorus and Artemia sp.) is used which is produced under controlled conditions (Lubzens, Tandler, \& Minkoff, 1989; Policar et al., 2007). Alternatively larvae of fresh water fish are reared under semi-extensive or extensive conditions in natural ponds where they feed on naturally growing zooplankton sources (Ludwig, 1999; Milstein, Valdenberg, \& Harpaz, 2006). Larvae are also reared in net cages which are placed in plankton containing water systems (Žiliukienè, 2005; Žiliukienė \& Ziliukas, 2006; Paragamian, Laude, Cain, Barron, \& Jensen, 2011). Formulated microdiets were tested with variable success as starter food for larvae of white sturgeon (Acipenser transmontanus) (Gawlicka, McLaughlin, Hung, \& de la Noüe, 1996), grass carp (Ctenopharygodon idella) and bighead carp (Aristichthys nobilis) (Rottmann, Shireman, \& Lincoln, 1991), zebrafish (Danio rerio) (Carvalho, Araújo, \& Santos, 2006), pike-perch (Sander lucioperca) (Ostaszewska, Dabrowski, Czuminska, Olech, \& Olejniczak, 2005), and loach (Misgurnus anguillicaudatus) (Wang, Hu, Cao, Yang, \& Wang, 2008). Combination of live food and formulated, commercially available diets were successfully used for feeding the larvae of goldfish (Kaiser, Endemann, \& Paulet, 2003), chub (Leuciscus cephalus), ide (Leuciscus idus), orfe (Leuciscus idus) and dace (Leuciscus leuciscus) (Kwiatkowski et al., 2008) and of vimba bream (Vimba vimba) (Hamáčková et al., 2009).

The culture of the burbot, Lota lota has high importance as it is endangered or extirpated in many European regions (Van Houdt, Hellemans, \& Volckaert, 2003; Van Houdt, de Cleyn, Perretti \& Volckaert, 2005). However, the larvae are difficult to rear as they are one of the smallest in fresh water. Only few data are available on this topic. Shiri Harzevili et al. (2003) reared Lota lota larvae with Brachionus calyciflorus and Artemia sp. with a survival rate of circa 70\%. Paragamian et al. (2011) reared them in pond cages resulting in an average survival rate of $18 \%$. 
In the present study we investigated alternative feeding methods for Lota lota larvae. We tested dried Artemia sp., Chlorella sp. and Spirulina sp., as this food is easy to prepare and to handle. We tested also formulated microdiets which composition bases on recipes of Carvalho et al. (1997), of Carvalho, Araújo, \& Santos (2006), and of Robin $\&$ Vincent (2003). These feeding regimes were compared with live zooplankton feeding which was harvested from a natural lake population.

\section{Method}

\subsection{Broodstock Fish and Egg Collection}

Lota lota derived from a wild population from lake Mondsee $\left(47^{\circ} 49^{\prime} \mathrm{N}, 13^{\circ} 24^{\prime} \mathrm{E}\right)$. The fish were kept in the fish farm Kreuzstein in flow through concrete tanks with a water supply of $2-31 \mathrm{~s}^{-1}$ and under a natural photoperiod. They were fed with dead rainbow trout fingerlings at a rate of circa $10 \%$ of their body weight every second day. Spawning was initiated by a decrease in temperature from $5^{\circ} \mathrm{C}$ to $1.5^{\circ} \mathrm{C}$ in the beginning of February. For spontaneous spawning 15 males and 15 females were transferred into a spawning tank $(1.5 \times 2 \times 0.5 \mathrm{~m}-$ length $\mathrm{x}$ width $\mathrm{x}$ height) with a false bottom consisting of a stainless steel mesh to prevent egg cannibalism 3 weeks before the expected date of spawning. Eggs were collected and incubated in Zug chars at a temperature of $1.7 \pm 1.2^{\circ} \mathrm{C}$ until the stage of ready to hatch embryos. To synchronize and shorten the hatching period the temperature was raised to $9^{\circ} \mathrm{C}$. Larvae were drained out of the Zug charrs using PVC tubes and stocked in rectangular tanks with a volume of $200 \mathrm{l}$. The tanks had initially a water height of circa $10 \mathrm{~cm}$ to facilitate the up-swimming of larvae and the inflation of the swimbladder. Five days after hatching was finished, the tanks were gradually filled to 2001.

\subsection{Larvae Feeding Experiments}

The feeding experiments are shown in the following flow chart. Feeding was started 10 days after hatching (dph).

\section{SMALL SCALE EXPERIMENTS}

Set up: 300 larvae/experiment, each experiment in duplicate, 4 feedings per day, feeding period $30 \mathrm{~d}$; density: 60 larvae/l. Quantities of food ingredients are reported in parenthesis in $\%(\mathrm{w}: \mathrm{w})$

\section{EXPERIMENT 1: Artemia $\mathrm{sp}$. and algae (300 mg/ feeding)}

EXPERIMENT 2: Formulated diets I (300 mg/ feeding)

\section{EXPERIMENT 3: Formulated} diets II (based on results of experiment 2) $(300 \mathrm{mg} /$ feeding)
(1) grinded artemia flakes

(2) grinded artemia flakes enriched with $0.5 \%(\mathrm{w} / \mathrm{w})$ Selco presso

(3) grinded artemia flakes (75), Chlorella (25)

(4) grinded artemia flakes (75), Spirulina (25)

(5) live zooplankton (5000 animals per feeding)

(a) fish meal (76), soya lecithin (13), fish oil (5)

(b) fish meal (76), soya lecithin (13), fish oil (5) in agar agar matrix ${ }^{1}$

(c) fish meal (84), soya lecithin (7), fish oil (3) in agar agar matrix ${ }^{1}$

(d) fish meal (91), soya lecithin (2), fish oil (1) in agar agar matrix ${ }^{1}$

(e) live zooplankton (5000 animals per feeding)

(I) fish meal (91), soya lecithin (2), fish oil (1) ${ }^{1}$

(II) fish meal (56), casein (35), soya lecithin (2), fish oil (1) ${ }^{1}$

(III) fish meal (75), dextrin (18), soya lecithin (0.8), fish oil (0.2) ${ }^{1}$

(IV) fish meal (56), artemia flakes (35), soya lecithin (2), fish oil (1) ${ }^{1}$ (V) live zooplankton (5000 animals per feeding)

\section{LARGE SCALE EXPERIMENT}

Set up: Best feeding regime from small scale experiments, food type: natural zooplankton, 25.000 larvae per tank, experiment in duplicate, feeding period $100 \mathrm{~d}$

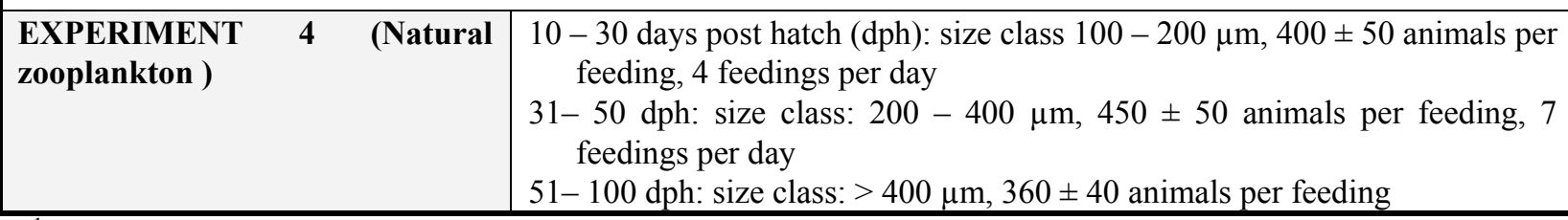

${ }^{1}$ contains $4 \%$ vitamin mix and $2 \%$ mineral mix

The small scale experiments were performed in modified Zug char glasses (Figure 1) at a flow through rate of 10 $\mathrm{ml} / \mathrm{min}$ and at natural photoperiod. Three-hundred larvae were stocked in each glass. Feeding was performed at 8 , 11,15 , and $19 \mathrm{~h}$ using $300 \mathrm{mg}$ of formulated microdiet food or $50 \mathrm{ml}$ zooplankton (animal density $=100,000 / 1$ ). 
Zug chars were cleaned daily from food remnants and dead larvae. Larvae survival was counted after 15 and $30 \mathrm{~d}$. After 15 days 20 larvae were sampled from each feeding regime for morphometric investigations (see viability determinations).

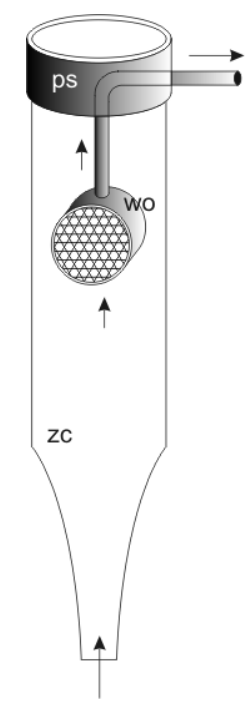

Figure 1. Modified Zug charr (zc) for on-feeding of Lota lota larvae. Water outlet (wo) occurred via a $10 \mathrm{~cm}$ plastic ring covered with a $200 \mu \mathrm{m}$ mesh size plankton net to avoid settling of larvae in the drainage. ps - plastic sleeve for fixation of the water outlet. Arrows indicate direction of water flow

In the large scale experiments circular tanks with a diameter of $90 \mathrm{~cm}$ and a height of $45 \mathrm{~cm}$ were used for $10-30$ dph larvae. Water inlet and outlet were peripherally at opposite sides of the tanks, the inlet at the bottom and the drainage at the surface. Settling of larvae at the drainage (as it is the case for circular tanks with a central bottom outlet) was avoided by this construction and zooplankton kept floating in the water body. Larvae were fed 3 times per day at 9,13 , and $18 \mathrm{~h}$. After $30 \mathrm{dph}$ the larvae were transferred into $5 \mathrm{~m}^{3}$ rectangular tanks $(5 \times 1.6 \times 0.6 \mathrm{~m}$, length $\mathrm{x}$ width $\mathrm{x}$ height) having the water inlet at one broadside and the water outlet at the opposite one. For larvae $>30 \mathrm{dph}$ feeding was performed 7 times per day from $8-18 \mathrm{~h}$ in $1.5 \mathrm{~h}$ intervals. The experiment was terminated $100 \mathrm{dph}$. Details of the feeding regimes are shown in Table 1 . The feeding experiment was made in duplicate in separate tanks, each with 25,000 larvae (determination of larvae numbers see below). For morphometric measurements and for control on malformations 50 larvae, respectively, were sampled from each tank at $0,20,30$, 50 , and $100 \mathrm{dph}$.

Table 1. Tank and feeding parameters used in the large scale experiment. *weight of zooplankton separated from water

\begin{tabular}{|c|c|c|c|}
\hline & $10-30 \mathrm{dph}$ & $31-50 \mathrm{dph}$ & $51-100 \mathrm{dph}$ \\
\hline \multicolumn{4}{|l|}{ Tank parameters } \\
\hline Tank volume (l) & 200 & 5000 & 5000 \\
\hline Stocking density (larvae/l) & $125 \pm 5$ & $4 \pm 1$ & $3.5 \pm 0.5$ \\
\hline Flow through rate $(1 / \mathrm{min})$ & $0.6 \mathrm{l} / \mathrm{min}$ & $15 \mathrm{l} / \mathrm{min}$ & $15 \mathrm{l} / \mathrm{min}$ \\
\hline \multicolumn{4}{|l|}{ Feeding parameters } \\
\hline Zooplankton fraction $(\mu \mathrm{m})$ & fine $(100-200)$ & medium $(200-400)$ & coarse $(>400)$ \\
\hline Feedings per day & 3 & 7 & 7 \\
\hline Zooplankton in g per day* & 30 & 175 & 560 \\
\hline Zooplankton in organisms per day $\left(\times 10^{3}\right)$ & $1200 \pm 150$ & $3150 \pm 350$ & $2520 \pm 390$ \\
\hline Organisms per feeding per larvae & $16 \pm 2$ & $23 \pm 2.5$ & $21 \pm 8$ \\
\hline Organisms per feeding per liter water & $2500 \pm 310$ & $100 \pm 10$ & $75 \pm 8$ \\
\hline
\end{tabular}




\subsection{Preparation of Formulated Microdiets}

Artemia flakes, dried Chorella and Spirulina, and Selco presso enrichment suspension (according to manufacturer instructions it contains high concentrations of docosahexaenoic acid and eicosapentaenoic acid, minerals, trace elements, and vitamins) were obtained from www.artemia-shop.de/. Fish meal, casein, and fish oil were obtained from a local angler shop, agar agar, soya lecithin, dextrin and the vitamin mix from a local pharmacy.

For experiment 1 Artemia flakes were grinded with a com mill to a particle size of $100-120 \mu \mathrm{m}$ and mixed with Chlorella or Spirulina powder as indicated in the flow chart. For enrichment, artemia flakes were soaked with a $0.5 \%$ suspension of Selco presso and dried in an incubator at $70^{\circ} \mathrm{C}$. Thereafter, the flakes were grinded as described above.

The formulated diets used in experiments 2 and 3 were prepared as follows: All ingredients were grinded to a particle size $<30 \mu \mathrm{m}$ in a ball mill. The proteinous ingredients indicated in the flow chart were mixed with water to form a dough and heated to $100^{\circ} \mathrm{C}$ for circa $15 \mathrm{~min}$ under constant stirring. Thereafter, the dough was cooled to circa $70^{\circ} \mathrm{C}$. Fish oil, soya lecithin (in form of a $5 \%$ solution), and vitamin mix were added in the required amounts and the components were mixed for additional $5 \mathrm{~min}$. This nutrient mixture was processed in two ways. For experiment 2 the ingredients were bound in agar agar matrix. A $2 \%$ agar agar solution was added to the $70^{\circ} \mathrm{C}$ warm nutrient mixture in a ratio of $1: 1(\mathrm{w}: \mathrm{w})$ and mixed for $10 \mathrm{~min}$. Then the mixture was spread on a tin foil in a $1-$ $3 \mathrm{~mm}$ thick layer and dried in an incubator at $70^{\circ} \mathrm{C}$ for $24 \mathrm{~h}$. For experiment 3 the nutrient mixture was dried without matrix embedding. Finally, the dry microdiets were grinded in a corn mill to a particle size of $100-150 \mu \mathrm{m}$ and stored air tight in a refrigerator at $4-5^{\circ} \mathrm{C}$ until use. Four $\%$ vitamin $\operatorname{mix}(\mathrm{w} / \mathrm{w})$ and $2 \% \operatorname{mineral} \operatorname{mix}(\mathrm{w} / \mathrm{w})$ was added to all formulated diets described in experiment 2 and 3 . The vitamin mix contained per $\mathrm{kg} 20 \mathrm{~g}$ ascorbic acid, $1 \mathrm{~g}$ biotine, $200 \mathrm{~g}$ choline chloride, $0.5 \mathrm{~g}$ cholecalciferol, $1 \mathrm{~g}$ cyanocobalamin, $2 \mathrm{~g}$ D-calcium pantothenate, $0.1 \mathrm{~g}$ folic acid, $1 \mathrm{~g}$ menadione, $30 \mathrm{~g}$ meso-inositol, $1 \mathrm{~g}$ niacin, $0.3 \mathrm{~g}$ pyridoxin, $0.34 \mathrm{~g}$ retinyl acetate, $400 \mathrm{mg}$ riboflavine, $100 \mathrm{mg}$ thiamin, $10 \mathrm{~g} \alpha$-tocopherol. The mineral mix contained per $\mathrm{kg} 215 \mathrm{~g} \mathrm{CaCO}_{3}, 500 \mathrm{~g}$ $\mathrm{CaHPO}_{4} 2 \mathrm{H}_{2} \mathrm{O}, 20 \mathrm{mg} \mathrm{CoSO}{ }_{4} 7 \mathrm{H}_{2} \mathrm{O}, 3 \mathrm{~g} \mathrm{CuSO}_{4} \cdot 5 \mathrm{H}_{2} \mathrm{O}, 20 \mathrm{~g} \mathrm{FeSO}_{4} \cdot 7 \mathrm{H}_{2} \mathrm{O}, 90 \mathrm{~g} \mathrm{KCl}, 40 \mathrm{mg} \mathrm{KL} 4 \mathrm{O}, 124 \mathrm{~g}$ $\mathrm{MgSO}_{4} \cdot 7 \mathrm{H}_{2} \mathrm{O}, 3 \mathrm{~g} \mathrm{MnSO}_{4} \cdot \mathrm{H}_{2} \mathrm{O}, 40 \mathrm{~g} \mathrm{NaCl}, 1 \mathrm{~g} \mathrm{NaF}, 4 \mathrm{~g} \mathrm{ZnSO} \cdot{ }_{4} \cdot 7 \mathrm{H}_{2} \mathrm{O}$

\subsection{Collection of Live Zooplankton}

Live zooplankton was collected from wild populations from lake Mondsee with plankton nets (AquaTech, Kitzbühl, Austria). The nets were dredged floating behind a boat in a depth of $10-15 \mathrm{~m}$ and at a cruising speed of $0.5 \mathrm{miles} / \mathrm{h}$. The dredging depth was adjusted depending on weather conditions and season. Using a sieve netting procedure three size fractions were collected. Sieve nets with $100 \mu \mathrm{m}$ as lower and $200 \mu \mathrm{m}$ as upper mesh size limit were used to collect a "fine" zooplankton fraction for feeding the $10-30 \mathrm{dph}$ old fish. The fine zooplankton fraction contained organisms with a width of $195 \pm 30 \mu \mathrm{m}$ and a length of $610 \pm 110 \mu \mathrm{m}$ (measured in subsamples fixed in $4 \%$ formaldehyde, $n=250$ from 10 different sampling dates).

Nets with a lower mesh size of $200 \mu \mathrm{m}$ and an upper mesh size of $400 \mu \mathrm{m}$ were used to collect a "medium" sized zooplankton fraction for the $31-50 \mathrm{dph}$ fish. These organisms had a body width of $305 \pm 55 \mu \mathrm{m}$ and a body length of $940 \pm 110 \mu \mathrm{m}(\mathrm{n}=375$ from 15 sampling dates $)$. A plankton net with a mesh size of $400 \mu \mathrm{m}$ was used to collect a coarse zooplankton fraction for $>50 \mathrm{dph}$ fish. Organisms in this fraction had a width of $470 \pm 260 \mu \mathrm{m}$ and a length of $1190 \pm 420 \mu \mathrm{m}$ ( $\mathrm{n}=400$ from 16 different sampling dates).

The quantities of collected zooplankton depended on the mesh size of the nets. With the $100-200 \mu \mathrm{m}$ sieve nets $0.08-0.12 \mathrm{~kg}$ zooplankton were collected per hour (weight of zooplankton separated from water). This represents an amount of $(3.2-4.8) \times 10^{6}$ animals (number of animals counted in a $10 \mathrm{mg}$ subsample and extrapolated with the total zooplankton mass). With the $200-400 \mu \mathrm{m}$ sieve net $0.2-0.5 \mathrm{~kg}$ zooplankton $\left(=[3.6-9.0] \times 10^{6}\right.$ animals $)$ were collected per hour, and with the $400 \mu \mathrm{m}$ net $1.7-1.9 \mathrm{~kg}\left(=[10.2-11.4]\right.$ x $10^{6}$ animals).

The collected zooplankton was washed out of the nets in 201 buckets and diluted to a density of 100.000 animals per litre. Preliminary adjustment was made visually by optical density estimations and exact adjustment by counting the animal numbers in $1000 \mu 1$ subsamples in Petri-dishes. Subsamples of the zooplankton fractions were fixed in $4 \%$ formaldehyde in 2 day intervals and the species composition and development stages were determined.

\subsection{Larvae Viability Evaluations}

The number of viable fish was determined $10 \mathrm{dph}$ (= initial stocking rate before the onset of feeding), $30 \mathrm{dph}$, and $100 \mathrm{dph}$. Ten dph and $30 \mathrm{dph}$ the total number of larvae was determined based on density determinations. Larvae were homogenously distributed in the tanks by gentle mixing and four 11 samples were taken. Larvae numbers per liter were counted and extrapolated to the total water volume of the tank. The numbers of juvenile fish was determined gravimetrically. The fish were transferred out of the tank and weighted. Thereafter the individual 
weight of 20 fish was determined and the total number of fish was calculated as total fish weight divided through the average individual fish weight. The 30 and $100 \mathrm{dph}$ survival rate was calculated as the percentage value of fish in relation to the number of stocked fish.

For the morphometric investigations the larvae were killed by an overdose of MS222 and photographed. in a stereomicroscope at 2 to 5 -fold magnification depending on the fish size. In the small scale experiment the larvae total length was measured, in the large scale experiment the larvae total length, head width and body width.

\subsection{Statistics}

The survival rate of fish was expressed as percentage of surviving fish relative to the total number of fish and reported as mean \pm standard deviation. Morphometric data are presented as mean \pm standard deviation, too. For statistical analysis, percentage data were transformed by angular transformation $(\arcsin \sqrt{ } \mathrm{P})$ and morphometric data by a logarithmic transformation. Survival rates were corrected for larvae numbers sampled for the morphometric determination. To determine if the experimental treatments resulted in significantly different survival rates, analysis of variance (ANOVA) with Waller Duncan posthoc test for the percentage data and Tukey-B posthoc test for the morphometric data was used.
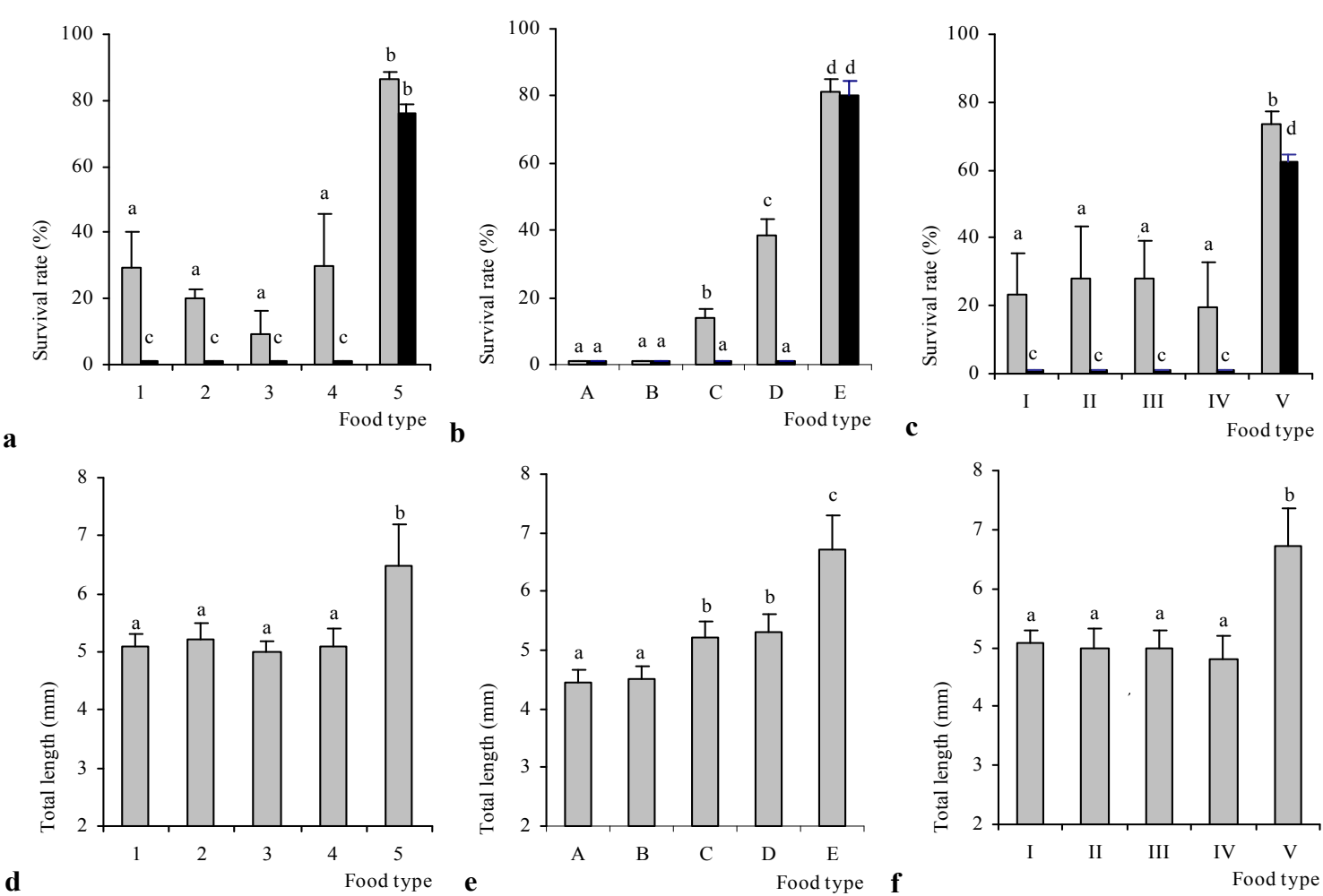

Figure 2. Survival and total length of Lota lota larvae after feeding with formulated diets and live zooplankton. Data are mean \pm S.D., those with different superscripts are significantly different $(\mathrm{P}<0.05)$. For survival rates sample number $(n)=2$ ( 2 tanks each with 300 larvae) and for total length $n=40$ (20 larvae from each tank).

Quantities of food ingredients are expressed in \% weight

(a) Survival rates and (d) total length obtained in experiment I: 1: grinded Artemia flakes (100), 2: grinded Artemia flakes (75) \& Chlorella (25), 3: grinded Artemia flakes (75) \& Spirulina (25), 4: enriched Artemia flakes (100), 5: live zooplankton.

(b) Survival rates and (e) total length obtained in experiment II: A: Fish meal (76), soya lecithin (13), fish oil (5) B: similar to (1) and in agar agar matrix, C: fish meal (84), soya lecithin (7), fish oil (3) in agar agar matrix, D: Fish meal (91), soya lecithin (2), fish oil (1) in agar agar matrix, E: live zooplankton

(c) Survival rates and (f) total length obtained in experiment III: Food types: I: Fish meal (91), soya lecithin (2), fish oil (1), II: fish meal (56), artemia flakes (35), soya lecithin (2), fish oil (1), III: fish meal (56), casein (35), soya lecithin (2), fish oil (1), IV: fish meal (75), dextrin (18), soya lecithin (0.8), fish oil (0.2) V: live zooplankton. 


\section{Results}

\subsection{Small Scale Experiments with Artificial Microdiets and Live Zooplankton}

In all 3 experiments the survival rates and the growth (total length) were high with live zooplankton (Figures 2a,b, c). With artificial microdiets in some treatments a percentage of up to $40 \%$ of the larvae survived for circa 15 days. Thereafter all larvae died.

In experiment 1 there were no differences in $15 \mathrm{~d}$ survival rates and in total length of larvae after $15 \mathrm{~d}$ (Figure $2 \mathrm{~d}$ ) between grinded artemia flakes (food type 1), enriched artemia flakes (type 4), grinded artemia flakes mixed with Chlorella sp. (type 2), and grinded artemia flakes mixed with Spirulina sp. (type 3) (Figure 2a).

In experiment 2 the $15 \mathrm{~d}$ survival of larvae and the total length of larvae after $15 \mathrm{~d}$ was significantly lower with agar agar bound microparticles than with microparticles having no agar agar matrix (compare food type A with type B) (Figures $2 \mathrm{~b}, 2 \mathrm{e}$ ). Also microparticle food with $\geq 7 \%$ soya lecithin and $\geq 3 \%$ fish oil (types $\mathrm{B}$ and $\mathrm{C}$ ) resulted in lower larvae survival and in lower larvae total length than microparticle food with only $2 \%$ soya lecithin and $1 \%$ fish oil (type D) (Figures 2b, 2e).

Experiment 3 showed that the supplementation of the microparticle food (food type I) with additional protein sources as grinded artemia flakes (type II) or caseine (type III) had no effect on the larvae survival and on the larvae total length after $15 \mathrm{~d}$ (Figures 2c, 2f). Also the supplementation of food type I with carbohydrates in form of dextran (type IV) did not affect the larvae survival rates and the larvae total length after $15 \mathrm{~d}$ (Figures 2c, 2f).

\subsection{Large Scale Experiment with Live Zooplankton}

The composition of the zooplankton fractions in aspects of species composition and development stages is shown in Figure 3. The 30 dph survival rate of Lota lota was $83 \%$ for tank 1 and $71 \%$ for tank 2 (Figure 4a). The $100 \mathrm{dph}$ survival rate was $78 \%$ and $66 \%$, respectively (Figure 2a). The growth rates did not significantly differ between tank 1 and tank 2 and therefore the pooled data set is presented. During the first 100 days of feeding the body length of Lota lota increased for circa 6-fold from 4.6 to $28.0 \mathrm{~mm}$ (Figure $4 \mathrm{~b}$ ), the body width for circa 5.5 -fold from 0.8 to $3.1 \mathrm{~mm}$, and the mouth width for almost 13-fold from 0.24 to $3.10 \mathrm{~mm}$ (Figure 4c). The percentage of larvae malformations was $<2 \%$.

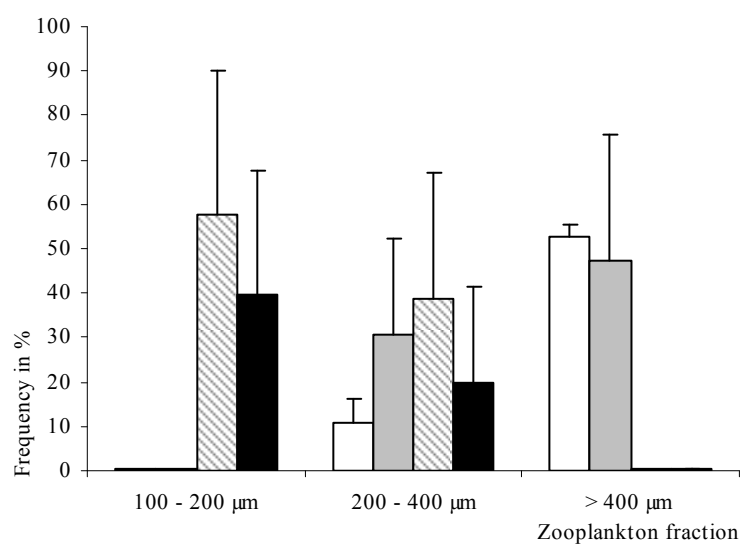

Figure 3. Species composition of the zooplankton fractions used for Lota lota feeding. White bars: adult cladocera (Daphnia sp.), grey bars: adult copepods (Cyclops sp. and Diaptomus sp.), shaded bars: copepodites, black bars: nauplii. Data are mean \pm standard deviation. $\mathrm{N}=20$ for the $<200 \mu \mathrm{m}$ fraction (sampling period: $10-30 \mathrm{dph}$ ), $\mathrm{n}=15$ for the $200-400 \mu \mathrm{m}$ fraction (sampling period: $31-50 \mathrm{dph}$ ), and 16 for the total fraction (sampling period 51-100 dph)

\section{Discussion}

The present study shows that not any of the tested artificial diets was successful for first feeding of Lota lota larvae. Only feeding with live zooplankton resulted in high survival rates and growth rates. The food ingredients used in experiment 1 were artemia flakes and artemia flakes in combination with dried algae. Although these ingredients derived from organisms which are generally used as larvae food for Lota lota and for other fish species (Lubzens et al., 1989; Paragamian et al., 2011), they were not suitable for Lota lota larvae in the dried form. This 
could have the following reasons: (a) Drying and processing could have decreased the nutritional value. (b) Food particles might be unstable in water and dissolve quickly and (c) food particles might not be ingested by the larvae. The latter two hypotheses are unlikely as food particles were observed sinking down from the water surface for up to $30 \mathrm{~min}$ and as ingestion of the food particles by larvae could be observed (unpublished data).
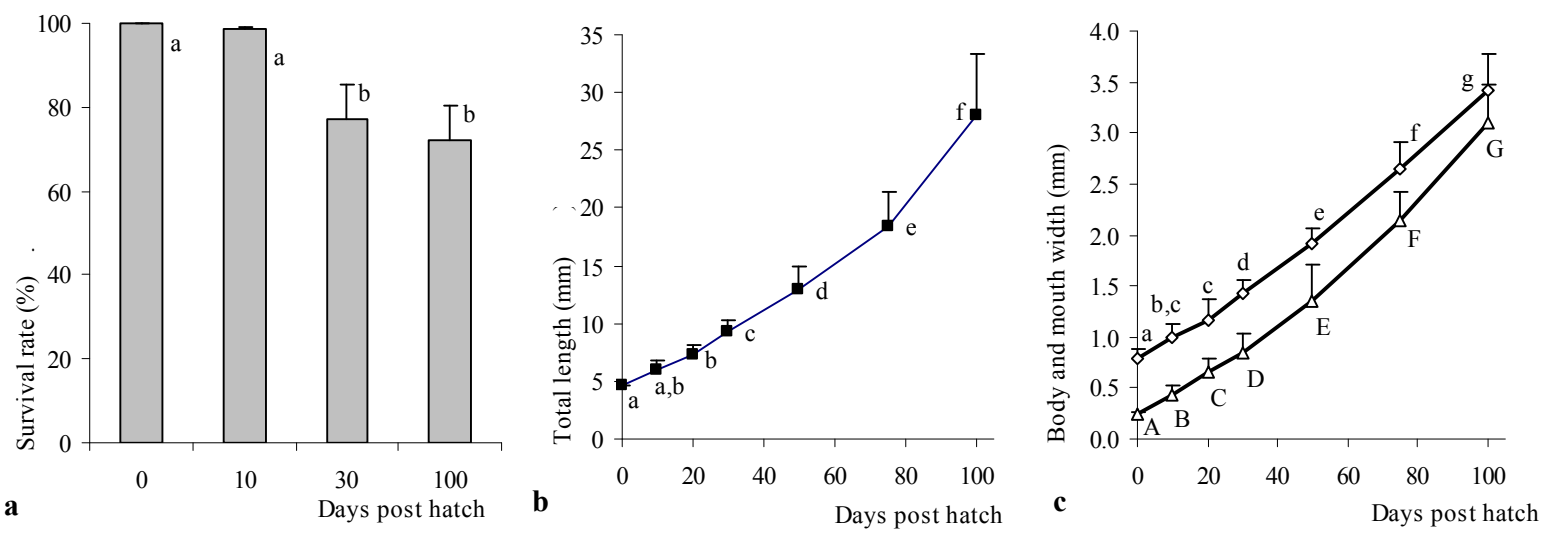

Figure 4. (a) Survival rates, (b) total length, (c) body width (rhombes) and mouth width (triangles) of Lota lota larvae during on-feeding with live zooplankton. Data are mean \pm S.D. In (a) $n=2$ for 2 tanks, in (b) and (c) data from the 2 tanks were pooled as there existed no significant differences $(n=100)$

The formulated diets used in experiments 2 and 3 contained $62-97 \%$ fishmeal, $2-13 \%$ soy bean lecithin, and $0.1-5 \%$ fish oil. Therefore, they were similar in their qualitative and quantitative composition to the diets used for onfeeding of Sander lucioperca larvae (74\% fish meal, $14 \%$ hydrolyzed fish meal, 0 - $13 \%$ soy bean lecithin, 0 13\% fish oil - Hamza, Mhetli, Ben Khemis, Cahu, \& Kestemont, 2008). Relatively similar mixtures were also tested for Sparus aurata larvae (69\% protein and protein hydrolysate, $12 \%$ soy bean lecithin, $5 \%$ fish oil - Robin and Vincent 2003). While in Sander lucioperca the tested microdiets resulted in a survival of circa $35 \%$ after 34 days post hatch (Hamza et al., 2008), no survival was obtained in Lota lota. Thus might indicate different food requirements for the two species. Although all onfeeding experiments with artificial diets were successless in Lota lota, the following three conclusions can be drawn from the experiments. (1) Fifteen d survival of larvae was significantly lower with agar agar bound microparticles than with microparticles having no agar agar matrix. This might be due to an indigestibility of agar agar for Lota lota larvae. As the particles are dehydrated for grinding, they swell quickly when immersed in water and might exceed the size limit for Lota lota larvae. Also the attractivity of the microbound particles might be low, as ingestion was observed only rarely. (2) Formulated diets with high lipid content were inadequate, as concentrations of $\geq 7 \%$ soya lecithin and $\geq 3 \%$ fish oil resulted in lower larvae survival than $2 \%$ soya lecithin and $1 \%$ fish oil. This is in contrast to results on the pike perch where lipids and phospholipids in the described concentration range had no effect. For onfeeding of zebrafish larvae lipid concentrations of $1-4 \%$ and phosphatidylcholine concentrations of $2-4 \%$ were successfully used (Carvalho et al., 2006). (3) The supplementation of the formulated diets with additional protein sources as grinded artemia flakes or casein and with carbohydrates in form of dextran did not improve the larvae survival.

The present study demonstrates that rearing of Lota lota larvae with live zooplankton collected from wild populations resulted in high fish survival rates of $>70 \%$ in the small scale and in the large scale experiments. Therefore, zooplankton feeding is also practicable under intensive culture conditions in fish farming. When adequate facilities (lakes or ponds) for zooplankton collection are available the feeding method has advantages as high numbers of food animals can be collected and simultaneously separated in size fractions with low effort.

In the present experiment the number of food animals administered for on-feeding was circa $15-25$ organisms per larvae and the food was adjusted to the requirements of the growing fish after 30 and $50 \mathrm{dph}$ by feeding bigger organisms (bigger zooplankton size fractions). Shiri Harzevili et al. (2003) used 140 Brachionus calyciflorus per Lota lota larvae. After 10 days, nutrition was changed to circa 25 Artemia per larvae. In both studies the survival rate of Lota lota was circa 70\% and the growth rate circa $200 \%$ after 35 days post hatch. When Lota lota larvae were stocked in pond cages the survival from stocking to final recovery in September was $18 \%$ and the average total length $49 \mathrm{~mm}$ (Paragamian et al., 2011). 
A zooplankton analysis demonstrated, that composition in aspects of species and development stages revealed daily qualitative and quantitative variability which is consistent with earlier observations on plankton communities (e.g. Ferrara, Vagaggini, \& Margaritora, 2005; Lahnsteiner, Kletzl, Weismann, 2009). The smallest zooplankton fraction of $200-400 \mu \mathrm{m}$, which was used as starter food for Lota lota larvae, contained mainly copepodites and nauplii while smaller organisms as rotifers and algae passed the $200 \mu \mathrm{m}$ net. Generally, rotifers are considered as optimal for on-feeding of small fish larvae (Lota lota: Shiri Harzevili et al., 2003; Ctenopharygodon idella, Aristichthys nobilis: Rottmann et al., 1991; Gobio gobio, Perca fluviatilis: Awaiss, Kestemont, \& Micha, 1992; different ornamental fish: Lim \& Wong, 1997; Lim, Dhert, \& Sorgeloos, 2003).

In summary the present investigations show, that on-feeding of Lota lota larvae with the tested artificial microdiets is impossible. As the larvae survival rates were zero in all experiments the diet composition is far away from the optimum and the development of suitable diets difficult. Onfeeding of Lota lota larvae with live zooplankton collected from wild populations is possible with high efficiency and is therefore a method suitable for fish farms and for intensive culture conditions. Possibly the molecular composition of natural zooplankton could serve as a basis to develop suitable formulated microdiets for Lota lota larvae.

\section{Acknowledgement}

The study was supported by a grant of the Bundesministerium für Land- und Forstwirtschaft, Umwelt und Wasserwirtschaft (www.lebensministerium.at), project number 100667.

\section{References}

Awaiss, A., Kestemont, P., \& Micha, J. (1992). Nutritional suitability of the rotifer, Brachionus calyciflorus Pallas for rearing freshwater fish larvae. Journal of Applied Ichthyology, 8, 263-270. http://dx.doi.org/10.1111/j.1439-0426.1992.tb00693.x

Carvalho, A. P., Escaffre, A. M., Teles, A. O., \& Bergot, P. (1997). First feeding of common carp larvae on diets with high levels of protein hydrolysates. Aquaculture International, 5, 361-367. http://dx.doi.org/10.1023/A:1018368208323

Carvalho, A. P., Araújo, L., \& Santos, M. M. (2006). Rearing zebrafish (Danio rerio) larvae without live food: evaluation of a commercial, a practical and a purified starter diet on larval performance. Aquaculture Research, 37, 1107-1111. http://dx.doi.org/10.1111/j.1365-2109.2006.01534.x

Ferrara, O., Vagaggini, D., \& Margaritora, F. G. (2002). Zooplankton abundance and diversity in Lake Bracciano, Latium, Italy. Journal of Limnology, 61, 169-175. http://dx.doi.org/10.4081/jlimnol.2002.169

Gawlicka, A., McLaughlin, L., Hung, S.O., \& de la Noüe, J. (1996). Limitations of carrageenan microbound diets for feeding white sturgeon, Acipenser transmontanus, larvae. Aquaculture, 141, 245-265. http://dx.doi.org/10.1016/0044-8486(95)01220-6

Hamáčková, J., Prokeš, M., Kozák, P., Peňáz, M., Stanny, L. A., Policar, T., \& Baruš, V. (2009). Growth and development of vimba bream (Vimba vimba) larvae in relation to feeding duration with live and/or dry starter feed. Aquaculture, 287, 158-162. http.//dx.doi.org/10.1016/j.aquaculture.2008.10.059

Hamza, N., Mhetli, M., Ben Khemis, I., Cahu, C., \& Kestemont, P. (2008). Effect of dietary phospholipid levels on performance, enzyme activities and fatty acid composition of pikeperch (Sander lucioperca) larvae. Aquaculture, 275, 274-282. http://dx.doi.org/10.1016/j.aquaculture.2008.01.014

Hsieh, C. H., \& Chiu, T. S. (2002). Summer spatial distribution of copepods and fish larvae in relation to hydrography in the northern Taiwan Strait. Zoological Studies, 41, 85-98.

Hsieh, C. H., Chen, C. S., \& Chiu, T. S. (2005). Composition and abundance of copepod and ichthyoplankton in the Taiwan Strait (western North Pacific) in relation to seasonal marine conditions. Marine and Freshwater Research, 56, 153-161. http://dx.doi.org/dx.doi.org/10.1071/MF04058

Kaiser, H., Endemann, F., \& Paulet, T. G. (2003). A comparison of artificial and natural foods and their combinations in the rearing of goldfish, Carassius auratus (L.). Aquaculture Research, 34, 943-950. http://dx.doi.org/10.1046/j.1365-2109.2003.00948.x

Kwiatkowski, M., Zarski, D., Kucharczyk, D., Kupren, K., Jamróz, M., Targoñska, K., ... Mamcarz, A. (2008). Influence of feeding natural and formulated diets on chosen rheophilic cyprinid larvae. Archives of Polish Fisheries, 16, 383-396. 
Lahnsteiner, F., Kletzl, M., \& Weismann, T. (2009). The risk of parasite transfer to juvenile fishes by live copepod food with the example Triaenophorus crassus and Triaenophorus nodulosus. Aquaculture, 295, 120-125. http://dx.doi.org/10.1016/j.aquaculture.2009.06.038

Lim, L. C., \& Wong, C. C. (1997). Use of the rotifer, Brachionus calyciflorus Pallas, in freshwater ornamental fish larviculture. Hydrobiologia, 358, 269-273.

Lim, L. C., Dhert, P., \& Sorgeloos, P. (2003). Recent developments in the application of live feeds in the $\begin{array}{lllll}\text { freshwater ornamental fish culture. Aquaculture, } & \text { 227, }\end{array}$ http://dx.doi.org/10.1016/S0044-8486(03)00512-X

Lubzens, E., Tandler, A., \& Minkoff, G. (1989). Rotifers as food in aquaculture. Hydrobiologia, 186, 387-400.

Ludwig, G. M. (1999). Zooplankton Succession and Larval Fish Culture in Freshwater Ponds. SRAC Publication No. 700. http://www.aquanic.org/publicat/usda_rac/efs/srac/700fs.pdf

Milstein, A., Valdenberg, A., \& Harpaz, S. (2006). Fish larvae - zooplankton relationships in microcosm simulations of earthen nursery ponds. I. Freshwater system. Aquaculture International, 14, 231-246. http://dx.doi.org/10.1007/s10499-005-9006-1

Ostaszewska, T., Dabrowski, K., Czuminska, K., Olech, W., \& Olejniczak, M. (2005). Rearing of pike-perch larvae using formulated diets - first success with starter feeds. Aquaculture Research, 36, 1167-1176. http://dx.doi.org/10.1111/j.1365-2109.2005.01332.x

Paragamian, V. L., Laude, C., Cain, K. D., Barron, J. M., \& Jensen, N. R. (2011). A novel experiment of rearing burbot larvae in cages. Journal of Applied Ichthyology, 27, 16-21. http://dx.doi.org/10.1111/j.1439-0426.2011.01838.x

Policar, T., Kozák, P., Hamácková, J., Lepicová, A., Musil, J., \& Kouril, J. (2007). Effects of short-time Artemia spp. feeding in larvae and different rearing environments in juveniles of common barbel (Barbus barbus) on their growth and survival under intensive controlled conditions. Aquatic Living Resources, 20, 175-183. http://dx.doi.org/10.1051/alr:2007029

Poulet, S. A., \& Williams, R. (1991). Characteristics and properties of copepods affecting the recruitment of fish larvae. Bulletin of the Plankon Society of Japan, Special Volume, 271-290.

Robin, J. H., \& Vincent, B. (2003). Microparticulate diets as first food for gilthead sea bream larva (Sparus aurata): study of fatty acid incorporation. Aquaculture, 225, 463-474. http://dx.doi.org/10.1016/S0044-8486(03)00310-7

Rottmann, R. W., Shireman, J. V., \& Lincoln, E. P. (1991). Comparison of three live foods and two dry diets for intensive culture of grass carp and bighead carp larvae. Aquaculture, 96, 269-280. http://dx.doi.org/10.1016/0044-8486(91)90157-3

Shiri Harzevili, A., De Charleroy, D., Auwerx, J., Vught, I., Van Slycken, J., Dhert, P., \& Sorgeloos, P. (2003). Larval rearing of burbot (Lota Iota L.) using Brachionus calyciflorus rotifer as starter food. Journal of Applied Ichthyology, 19, 84-87. http://dx.doi.org/10.1046/j.1439-0426.2003.00442.x

Van Houdt, J. K., Hellemans, B., \& Volckaert, F. A. M. (2003). Phylogenetic relationships among Palearctic and Nearctic burbot (Lota lota): Pleistocene extinctions and recolonisation. Molecular Phylogenetics and Evolution, 29, 599-612. http:// dx.doi.org/10.1016/S1055-7903(03)00133-7

Van Houdt, J. K., de Cleyn, L., Perretti A., \& Volckaert F. A. M. (2005). A mitogenic view on the evolutionary history of the Holarctic freshwater gadoid, burbot (Lota lota). Molecular Ecology, 14, 2445-2457. http://dx.doi.org/10.1111/j.1365-294X.2005.02590.x

Wang, Y., Hu, M., Cao, L., Yang, Y., \& Wang, W. (2008). Effects of daphnia (Moina micrura) plus chlorella (Chlorella pyrenoidosa) or microparticle diets on growth and survival of larval loach (Misgurnus anguillicaudatus). Aquaculture International, 16, 361-368. http://dx.doi.org/10.1007/s10499-007-9150-x

Žiliukienè, V. (2005). The diet of Abramis brama (L.) larvae reared in illuminated cages. Journal of Applied Ichthyology, 21, 406-409. http://dx.doi.org/10.1111/j.1439-0426.2005.00591.x

Ziliukiene, V., \& Ziliukas, V. (2006). Feeding of early larval pike Esox lucius L. reared in illuminated cages. Aquaculture, 258, 378-387. http://dx.doi.org/10.1016/j.aquaculture.2006.04.010 